\title{
PENINGKATAN PROFESIONALITAS GURU SDN 4 MESUJI TIMUR MELALUI PROGRAM T2KT
}

\section{IMPROVING SDN 4 EAST MESUJI TEACHERS' PROFESIONALISM THROUGH T2KT PROGRAM}

\author{
Lulud Oktaviani' $^{1)}$, Dyah Aminatun ${ }^{2)}$, Imam Ahmad ${ }^{3)}$ \\ ${ }^{1,2}$ Pendidikan Bahasa Inggris, Fakultas Sastra dan Ilmu Pendidikan, Universitas Teknokrat \\ Indonesia \\ ${ }^{3}$ Sistem Informasi, Fakultas Teknik dan Ilmu Komputer, Universitas Teknokrat Indonesia \\ ${ }^{1}$ Email: lulud_oktaviani@teknokrat.ac.id
}

\begin{abstract}
Abstrak: Mengajar merupakan suatu kewajiban bagi guru untuk mencerdaskan anak bangsa. Namun, untuk peningkatan kesejahteraan dan profesionalitasnya, guru harus mengurus kenaikan pangkat dan juga sertifikasi demi tercapainya tingkat kesejahteraan yang lebih tinggi. Di dalam pengurusannya, guru disyaratkan salah satunya adalah untuk menulis karya ilmiah. Faktanya, tidak semua guru familiar dan produktif dengan penulisan karya ilmiah, terutama guruguru yang mengajar didaerah Pusat Lintas Batas Negara (PLBN). Pengabdian ini dilaksanakan di SDN 4 Mesuji Timur yang merupakah salah satu sekolah percontohan di Mesuji Timur. Berdasarkan hasil interview dan pengumpulan data awal, $80 \%$ guru terkendala dalam pengurusan sertifikasi maupun kenaikan pangkat dikarenakan penulisan karya ilmiah. Oleh karena itu, pengabdian ini dilakukan untuk membantu guru-guru dalam menulis karya ilmiah melalui program Temukan, Tuliskan, Konsultasikan, dan Terbitkan (T2KT). Pada akhirnya, dampak positif dirasakan guru-guru dengan meningkatnya pemahaman dan pengetahuan tentang penulisan karya ilmiah yang lebih baik untuk menunjang kenaikan pangkat dan juga sertifikasi, penggunaan media pembelajaran terbarukan, dan publikasi artikel ilmiah.
\end{abstract}

Kata Kunci: Profesionalitas, Guru, T2KT.

Abstract: Teaching is an obligation for teachers to educate the nation's children. However, to improve welfare and professionalism, teachers must take care of promotion and certification in order to achieve a higher level of welfare. For documents administration, one of the requirements for teachers is to write scientific papers. In fact, not all teachers are familiar and productive with writing scientific papers, especially teachers who teach in the Central Cross-Border Area (PLBN). This service was carried out at SDN 4 East Mesuji which is one of the pilot schools in East Mesuji. Based on the results of interviews and preliminary data collection, $80 \%$ of teachers were constrained in processing certification or promotion due to writing scientific papers. Therefore, this service was carried out to assist teachers in writing scientific papers through the Find, Write, Consult, and Publish (T2KT) program. In the end, the positive impact was felt by teachers with increased understanding and knowledge of better scientific writing to 


\section{INTEGRITAS : Jurnal Pengabdian}

Vol 4, No 2, Desember 2020

ISSN $2580-7978$ (cetak) ISSN 2615-0794 (online)

support promotion and certification, use of renewable learning media, and publication of scientific articles.

Keywords: Profesionalism, Teacher, T2KT.

\section{PENDAHULUAN}

Pekerjaan sebagai guru adalah pekerjaan yang tidak dapat dipandang sebelah mata dewasa ini, terlebih lagi guru sudah dianggap sebagai pekerjaan profesional. Hal ini tercantum dalam Undang-Undang Negara Republik Indonesia Nomor 14 tahun 2005 tentang Guru dan Dosen bahwa: "Guru adalah pendidik profesional dengan tugas utama mendidik, mengajar, membimbing, mengarahkan, melatih, menilai dan mengevaluasi peserta didik pada pendidikan anak usia dini jalur pendidikan formal, pendidikan dasar, dan pendidikan menengah.” Oleh karenanya, untuk lebih menguatkan arti professional tersebut pemerintah memberikan sertifikat kepada guru yang memenuhi kualifikasi sebagai guru professional sebagaimana tercantum dalam Permendikbud Nomor 37 Tahun 2017 Pasal 1 Ayat 2 bahwa "Sertifikat pendidik adalah bukti formal sebagai pengakuan yang diberikan kepada guru sebagai tenaga professional.”

Selain dalam bentuk sertifikat, sertifikasi juga berupa tunjangan sebagai harga dari keprofesionalitasan tersebut. Dengan istilah tenaga professional maka wajar jika penghasilan guru juga harus disesuaikan dengan bentuk keprofesionalan tersebut. Hal itulah yang membedakan antara pekerjaan guru dulu yang sekarang. Siswanto (2008) menyatakan bahwa tujuan pemerintah dari sertifikasi guru ini salah satunya adalah meningkatkan kesejahteraan guru dengan memberikan satu kali gaji setiap bulannya namun dengan diimbangi dengan meningkatnya kualitas pembelajaran dan guru itu sendiri.

Oleh karena itu, guru harus benar-benar melaksanakan keprofesionalitasannya tersebut untuk disebut sebagai guru professional, diantaranya guru harus aktif dalam meningkatkan kemampuan dirinya, salah satunya adalah pembuatan karya ilmiah yang didasari oleh kegiatan atau aktifitas belajar mengajar dikelas terutama dengan menggunakan media yang terbarukan. 


\section{INTEGRITAS : Jurnal Pengabdian}

Vol 4, No 2, Desember 2020

ISSN $2580-7978$ (cetak) ISSN 2615 - 0794 (online)

Seperti dikatakan oleh Shabir (2015) bahwa seorang guru berkewajiban dalam meningkatkan keprofesionalitasnnya dalam perencanaan pengajaran dan peningkatan kompetensi secara berkala. Dengan kata lain, guru juga harus aktif secara berkala mengurus jenjang jabatan fungsional guru agar secara berkesinambungan tunjangan sertifikasi terus dapat diperoleh.

Secara singkat, guru harus membuat karya tulis untuk mengurus jenjang jabatan fungsional, selanjutnya dengan meningkatnya jenjang jabatan fungsional maka tunjangan sertifikasi akan meningkat. Ketika seorang guru tidak mengurus jenjang jabatan fungsional dalam waktu kurun tertentu, maka tunjangan sertifikasi juga akan di berhentikan sementara sampai guru tersebut aktif mengembangkan diri sebagai salah satu syarat tenaga professional. Ekosusilo (2014) mengungkapkan bahwa penulisan karya ilmiah masuk ke dalam unsur utama yang total nilainya $90 \%$ untuk kepengurusan jenjang jabatan fungsional guru. Lebih lengkapnya pada gambar dibawah ini:

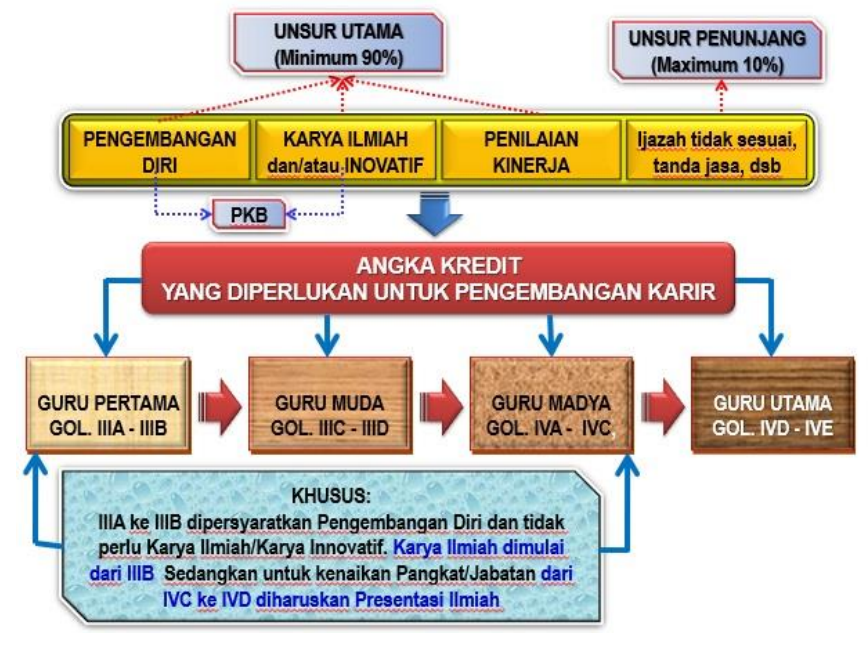

Gambar 1. Unsur Jenjang Jabatan Guru (Sumber: Ekosusilo, 2014)

Dari Gambar 1 diatas, dapat dilihat bahwa pembuatan karya ilmiah diwajibkan ketika guru akan mengurus jenjang jabatan dari golongan IIIB ke golongan IIIC dan seterusnya, bahkan guru harus mempresentasikan karya ilmiah untuk kepengurusan jenjang jabatan dari IVC ke golongan IVD. Oleh sebab itu, guru harus membiasakan diri membuat karya tulis sejak awal karena jika tidak 


\section{INTEGRITAS : Jurnal Pengabdian}

Vol 4, No 2, Desember 2020

ISSN $2580-7978$ (cetak) ISSN 2615 - 0794 (online)

terbiasa membuat karya tulis maka pasti akan timbul berbagai macam kesulitan pada saat kepengurusan jejang jabatan.

Kesulitan dalam pembuatan karya tulis inilah yang menjadi permasalahan utama bagi guru-guru di SDN 4 Mesuji Timur. Permasalahan utama yang dihadapi yaitu (1) kendala proses pembuatan karya tulis ilmiah dan (2) minimnya pengetahuan mengenai macam dan penggunaan media terutama media berbasis teknologi sebagai salah satu variable dalam pengajaran dan penulisan karya ilmiah. Secara singkat terdapat dua permasalahan dari dua kajian ilmu yang berbeda yaitu dari Bidang Pendidikan mengenai penulisan karya ilmiah khususnya Penelitian Tindakan Kelas (PTK) dan dari Bidang Teknologi Sistem Informasi mengenai macam media berbasis teknologi. Untuk melihat secara jelas mengenai penulisan karya ilmiah yang sudah dibuat oleh guru SDN 4 Mesuji Timur selain skripsi akhir mereka selama menjadi guru dapat dilihat pada Gambar 2 dan 3 sebagai berikut:

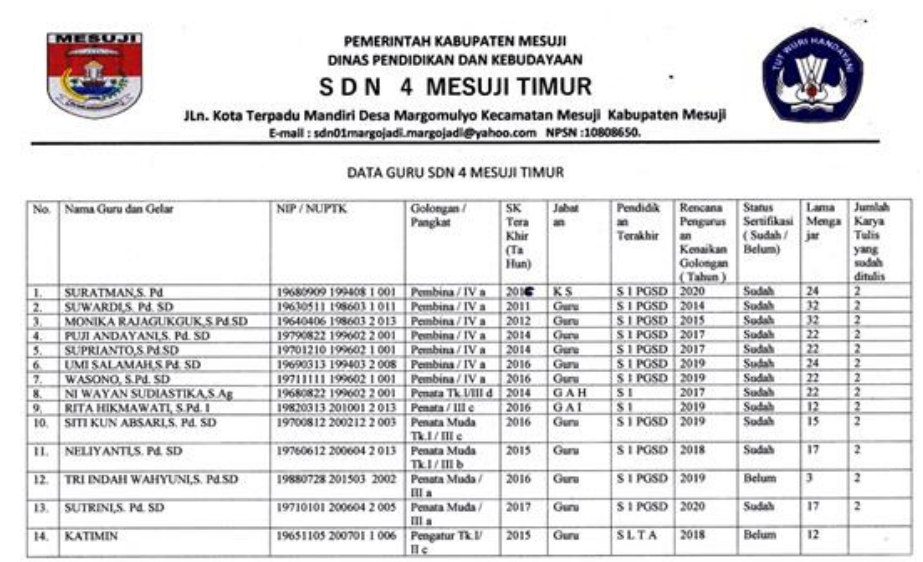

Gambar 2. Data Guru SDN 4 Mesuji Timur (1)
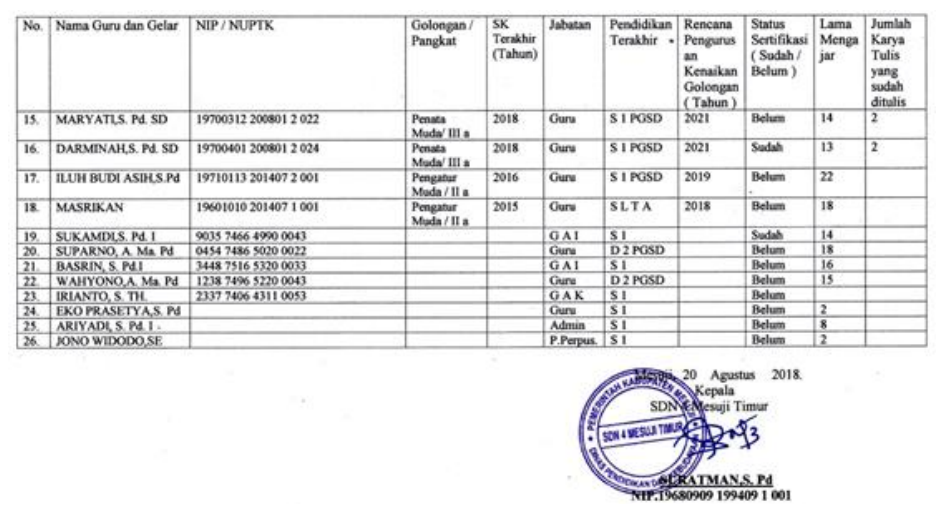

Gambar 3. Data Guru SDN 4 Mesuji Timur (2) 


\section{INTEGRITAS : Jurnal Pengabdian}

Vol 4, No 2, Desember 2020

ISSN 2580 - 7978 (cetak) ISSN 2615 - 0794 (online)

Dari Gambar 2 dan 3 diatas dapat dilihat bahwa pembuatan karya ilmiah oleh Guru SDN 4 Mesuji Timur masih sangat minim dengan rata-rata dua karya tulis (selain skripsi) selama menjadi guru. Terlebih lagi tujuh orang sudah berjenjang jabatan guru IVA yang akan mengurus jenjang jabatan ke IVB. Selain minimnya pembuatan karya tulis, lima guru juga sudah terlambat dalam kepengurusan jenjang jabatan seperti terihat pada gambar diatas dan alasannya adalah kendala dalam pembuatan karya tulis ilmiah (data alasan didapat melalui wawancara pada 24 Agustus 2018). Terlebih lagi, dua guru bisa mengurus jenjang jabatan pada tahun 2018, enam guru bisa mengurus jenjang jabatan pada tahun 2019, dan selebihnya pada tahun 2020 dan 2021. Warsono (2017) mengatakan bahwa guru harus diingatkan baik dalam bentuk peraturan atau yg lainnya dimana guru sebagai tenaga professional harus menjadi lebih baik dan dievaluasi bahkan ketika mereka sudah memiliki sertifikat pendidik. Menanggapi hal tersebut, pemerintah pun sudah melakukan hal serupa dengan akan memberhentikan tunjangan sertifikasi ketika guru tidak mengurus kenaikan jabatan dalam kurun waktu tertentu.

Hasil wawancara pada 24 Agustus 2018 menunjukkan bahwa $80 \%$ guru menyatakan bahwa kendala terbesar pembuatan karya tulis ilmiahnya dikarenakan tidak tahu apa yang harus diteliti. Kemudian, minimnya wadah atau tempat untuk berkonsultasi mengingat infrastruktur di Kabupaten Mesuji sendiri terutama jalan masih banyak rusak dan berlubang sehingga menjadi kendala lain untuk guru SDN 4 Mesuji Timur berkonsultasi ke kantor Kabupaten Mesuji. Berdasarkan data dan masalah diatas, maka sebagai dosen dari ibukota provinsi melakukan pengabdian pada tahun pelaksanaan 2019 ke Kabupaten Mesuji khususnya di SDN 4 Kecamatan Mesuji Timur guna menyelesaikan masalah yang sedang dihadapi oleh guru disekolah tersebut dengan Nomor Surat Perjanjian Penugasan 001/LPPM-UTI/FSIP/PKM-MONO/V/2019.

Pada akhirnya, kegiatan pengabdian ini bertujuan agar guru-guru dapat meningkatkan kompetensi mereka mengenai macam-macam media pembelajaran berbasis teknologi dan penelitian tindakan kelas yang selanjutnya akan dihasilkan 


\section{INTEGRITAS : Jurnal Pengabdian}

Vol 4, No 2, Desember 2020

ISSN 2580 - 7978 (cetak) ISSN 2615 - 0794 (online)

karya ilmiah berupa Penelitian Tindakan Kelas (PTK). Secara tidak langsung, penggunaan media pembelajaran berbasis teknologi dapat meningkatkan kegiatan proses belajar mengajar dikelas (Oktaviani dan Desiarti, 2017) dan dapat ditulis kedalam karya ilmiah yang dapat menunjang kenaikan jabatan fungsional. Hal tersebut pun dapat menunjang sertifikasi guru.

\section{METODE}

SD Negeri 4 Mesuji Timur dipilih karena sekolah ini terletak di daerah prioritas dan merupakan sekolah dasar model percontohan di kecamatan Mesuji Timur. Ditambah lagi, pembuatan karya tulis ilmiah merupakan suatu syarat wajib dan penunjang profesionalitas guru (Noorjanah, 2014), terutama yang ingin melakukan sertifikasi dan mengajukan kenaikan pangkat.

Metode yang digunakan dalam kegiatan ini meliputi pendekatan institusional, metode diskusi, pendekatan partisipatif, dan pemberian workshop/pelatihan mengenai pembuatan karya tulis ilmiah melalui penerapan media pembelajaran berbasis teknologi. Pendekatan institusional dilakukan dengan melakukan komunikasi mengenai masalah yang sedang dihadapi mitra dan kebutuhan mitra. Tahap selanjutnya adalah melakukan diskusi mengenai solusi yang ditawarkan kepada mitra serta teknis pelaksanaan kegiatan. Setelah mendapat persetujuan mitra, selanjutnya dilakukan pendekatan partisipatif yaitu keterlibatan pelaksana kegiatan dalam pemberian informasi dan materi, pelatihan pembuatan karya tulis ilmiah melalui penggunaan media, serta pendampingan dalam proses ketercapaian kebutuhan mitra. Pada tahap akhir adalah peserta kegiatan diharapkan untuk dapat menerapkan T2KT (Temukan, Tulis, Konsultasikan, Terbitkan), yaitu dengan mulai menemukan masalah penelitian yang terjadi di sekitarnya, menulis bagian-bagian dari penelitian seperti latar belakang masalah, hingga temuan penelitian, mengonsultasikan masalah dan rumusan penelitan kepada narasumber, serta menerbitkan karya tulisnya. Dalam hal ini, para guru difokuskan untuk dapat menguasai jenis penelitian tertentu, terutama Penelitian Tindakan Kelas yaitu "penelitian yang dilakukan dikelas guna 


\section{INTEGRITAS : Jurnal Pengabdian}

Vol 4, No 2, Desember 2020

ISSN $2580-7978$ (cetak) ISSN 2615 - 0794 (online)

untuk memperbaiki atau meningkatkan mutu pembelajaran" (Permana, 2010). Selanjutnya pemberian kuisioner diberikan kepada peserta pelatihan sebagai tahap evaluasi umpan balik dari peserta terhadap kegiatan yang telah dilaksanakan

\section{HASIL DAN PEMBAHASAN}

Hasil dari program pengabdian ini adalah peningkatan pemahaman guru terhadap berbagai macam media pembelajaran yang dapat digunakan dalam proses belajar mengajar. Untuk mengukur hal tersebut, penulis mendata beberapa media yang sudah digunakan untuk mengajar dikelas selama proses pengabdian ini diantaranya:

Tabel 1. Data Penggunaan Media oleh Guru

\begin{tabular}{cc}
\hline Jumlah Guru & Media Pembelajaran \\
\hline 4 & Slidesgo \\
\hline 8 & Video \\
\hline 6 & Powerpoint \\
\hline 3 & Audio \\
\hline 2 & Powtoon \\
\hline
\end{tabular}

Selain penggunaan media untuk melihat pemahaman guru-guru selama proses pengabdian, penulis juga memberikan angket pendapat Likert Scale sebelum dan sesudah kegiatan pengabdian ini berlangsung yang pada akhirnnya mendapat hasil berupa nilai rata-rata yaitu: Mean Sebelum Pengabdian: 2,30 dan Mean Sesudah Pengabdian: 3,82. Lebih lanjut, untuk meyakinkan pemahaman guru-guru, peningkatan pemahaman juga diukur dengan diadakannya Seminar Guru yang pematerinya adalah perwakilan dari guru SDN 4 Mesuji Timur yaitu Umi Salamah S.Pd. SD. dan pesertanya adalah perwakilan dari guru-guru SD di lingkungan Mesuji Timur. Seminar Guru ini dilaksanakan pada tanggal 10 Agustus 2019 dan dihadiri oleh perwakilan guru dari beberapa sekolah di lingkungan Mesuji Timur dengan jumlah peserta 32 guru serta didampingi oleh dosen-dosen dalam tim pengabdian ini. 


\section{INTEGRITAS : Jurnal Pengabdian}

Vol 4, No 2, Desember 2020

ISSN 2580 - 7978 (cetak) ISSN 2615 - 0794 (online)

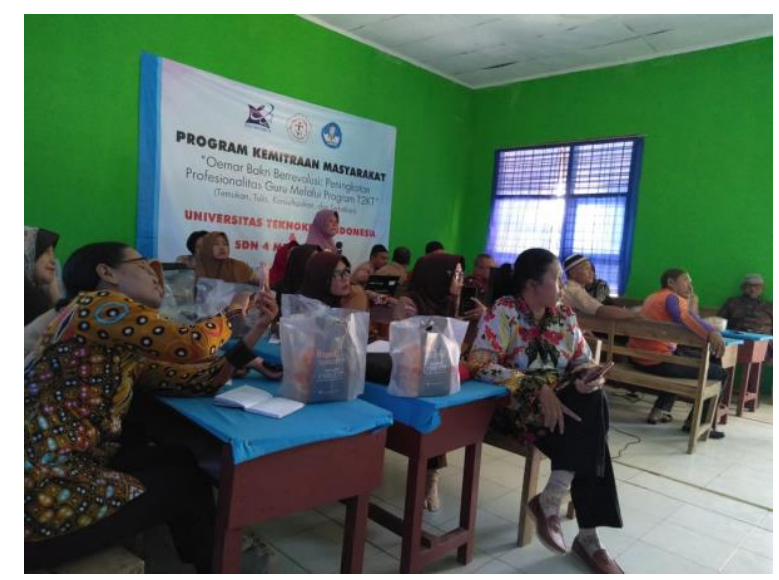

Gambar 4. Seminar Guru

Pada Seminar Guru juga diberikan angket kepada para peserta yang hadir untuk mengetahui apakah pemaparan Ibu Umi pada Seminar Guru dapat meningkatkan pemahaman peserta mengenai media pembelajaran dan penelitian tindakan kelas. Adapun rata-rata nilai angketnya adalah Mean Sebelum Pengabdian: 2,29 dan Mean Sesudah Pengabdian: 3,47.

Selanjutnya, peningkatan keberdayaan masyarakat juga dapat dilihat dengan adanya guru yang menjadi pemateri pada seminar nasional dan menerbitkan artikel pada prosiding dalam pertemuan ilmiah lokal pada kegiatan Seminar Nasional Pendidikan FKIP Universitas Lampung pada tanggal 28 September 2019 di Hotel Bukit Randu Bandarlampung.

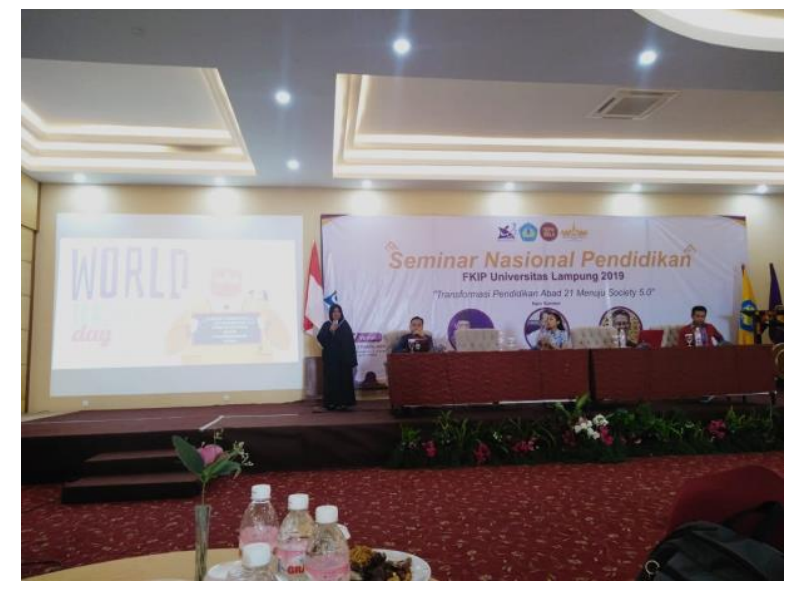

Gambar 5. Guru SDN 4 Mesuji Timur menjadi Pemateri Seminar Nasional 


\section{INTEGRITAS : Jurnal Pengabdian}

Vol 4, No 2, Desember 2020

ISSN $2580-7978$ (cetak) ISSN 2615 - 0794 (online)

Berdasarkan hasil diatas, maka program pengabdian tahun pelaksaan 2019 melalui skim Program Kemitraan Masyarakat (PKM) dapat meningkatkan pengetahuan masyarakat yang dalam hal ini adalah guru-guru di Mesuji Timur, khususnya SDN 4 Mesuji Timur. Peningkatan ini dapat dilihat atau dihitung secara kuantitatif baik dalam hal penggunaan media pembelajaran dimana guruguru juga berkonsultasi mengenai media dan penggunaannya pada materi yang akan diajarkan melalui kegiatan Temukan, Tulis, Konsultasikan, dan Terbitkan (T2KT). Pada akhirnya media pembelajaran yang sudah digunakan, dituliskan dalam bentuk tulisan ilmiah Penelitian Tidakan Kelas. Selanjutnya, penelitian tersebut dapat digunakan untuk mengurus kenaikan jabatan guru yang terintegrasi dengan besaran sertifikasi yang akan diterima oleh masing-masing guru. Adapun proses kegiatan pengabdian ini dibagi menjadi delapan pertemuan seperti digambarkan dalam tabel 2 dibawah ini:

Tabel 2. Kegiatan Kunjungan Pengabdian

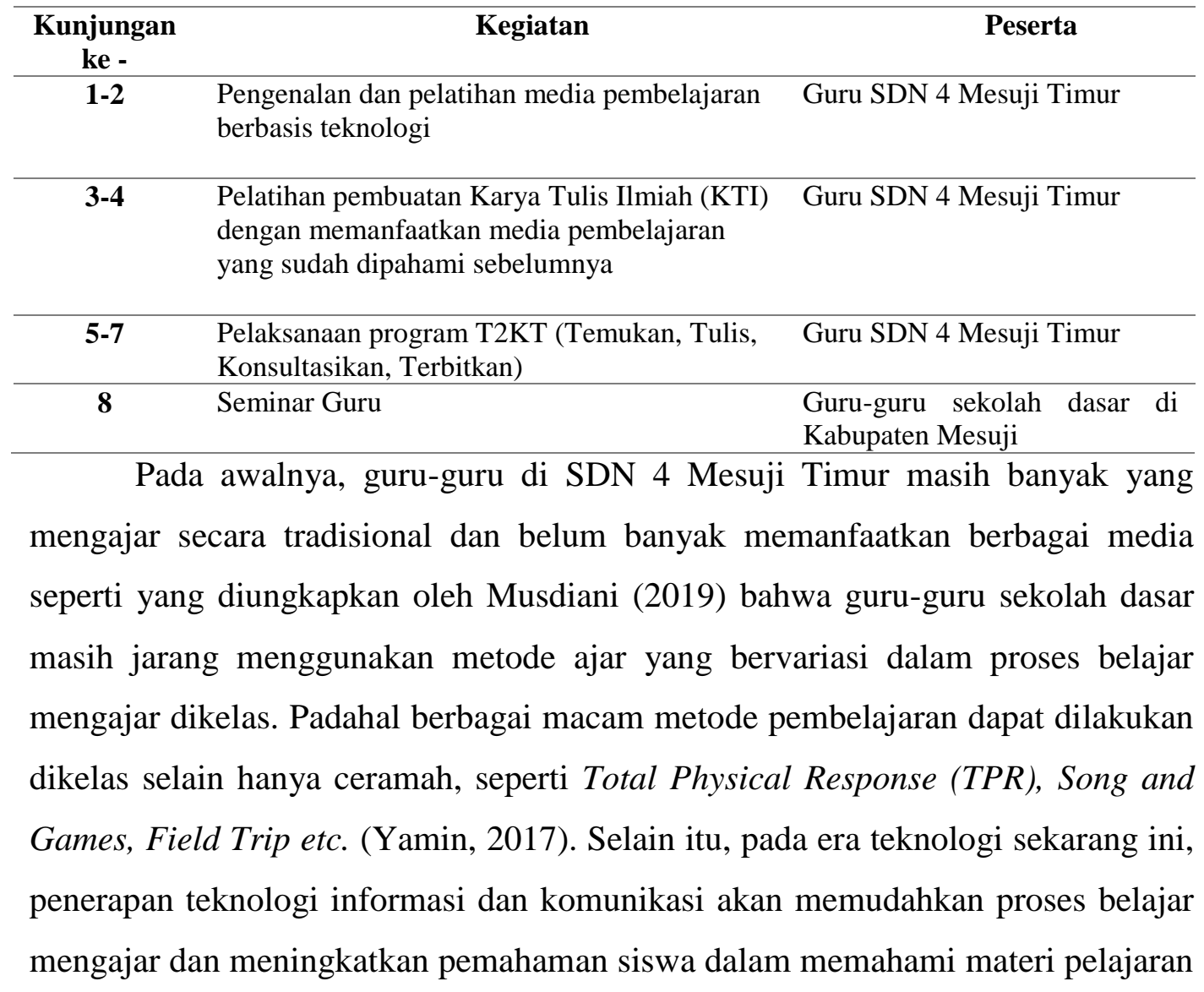




\section{INTEGRITAS : Jurnal Pengabdian}

Vol 4, No 2, Desember 2020

ISSN 2580 - 7978 (cetak) ISSN 2615 - 0794 (online)

khususnya di daerah terpencil (Azhariadi dkk., 2019). Oleh karena itu, setelah program pengabdian ini terlaksana, ada peningkatan penggunaan media pembelajaran dalam proses belajar mengajar dikelas dimana guru-guru mulai memanfaatkan berbagai macam media pembelajaran yang terbarukan. Sehingga, terjadi variasi metode ajar yang dapat meningkatkan ketertarikan siswa terhadap materi ajar. Hal ini diungkapkan oleh Salamah dan Oktaviani (2019) bahwa penggunaan teknologi sebagai media pembelajaran dapat meningkatkan kemampuan siswa khususnya materi yang membutuhkan banyak visualisasi. Terlebih lagi, penggunaan media pembelajaran juga dapat memberikan beberapa manfaat diantaranya yaitu membuat proses belajar mengajar lebih efektif dan efesien, mengurangi kebosanan siswa/peserta didik, mengatasi berbagai persoalan, dan sebagai alat atau media informasi yang komprehensif (Tafonao, 2018). Ditambah lagi, karakteristik siswa sekolah dasar yang hanya memiliki konsentrasi yang singkat, membutuhkan suatu media atau metode ajar yang dapat menarik perhatian mereka dan meningkatkan motivasi belajar (Sinaga dan Oktaviani, 2020).

Selain dari mengikuti workshop dan mengetahui manfaat penggunaan media pembelajaran berbasis teknologi diatas serta menerapkannya dikelas dan menjadikannya sebuah KTI, guru-guru juga harus benar-benar paham dan mengambil manfaat dari program pengabdian ini. Sehingga pada saat program pengabdian ini berakhir, guru-guru dapat melanjutkan penggunaan media dan pembuatan KTI. Oleh karenanya, tim pengabdian mengadakan seminar guru dimana pematerinya adalah guru dengan hasil workshop terbaik, baik dalam hal angket ataupun hasil akhir KTInya.

\section{KESIMPULAN}

Dengan dilaksanakannya pelatihan penulisan karya ilmiah dan juga penggunaan media pembelajaran melalui T2KT, pemahaman guru-guru semakin bertambah dalam menerapkan media maupun metode pebelajaran yang tepat dalam menyelesaikan masalah di kelas. Selain itu kemampuan guru-guru dalam 


\section{INTEGRITAS : Jurnal Pengabdian}

Vol 4, No 2, Desember 2020

ISSN $2580-7978$ (cetak) ISSN 2615-0794 (online)

menuliskan karya ilmiah juga meningkat, terutama dalam menuliskan Penelitian Tindakan Kelas karena masalah yang diangkat adalah berasal dari kelas masingmasing guru, sehingga guru dapat dengan mudah mengidentifikasi penyelesaiannya. Di dalam penulisannya, guru dengan aktif mengonsultasikan kepada narasumber, dalam hal ini adalah dosen untuk dapat terus memperbaiki kualitan penulisan karya ilmiahnya. Selanjutnya, guru dan dosen bersama-sama memperbaiki hasil akhir penelitian yang kemudian dapat dipresentasikan oleh guru di seminar pendidikan, maupun sebagai syarat guru dalam mengajukan kenaikan jabatan fungsionalnya. Hal ini tentu dinilai bermanfaat bagi peningkatan keprofesionalitasan guru dan tingkat kesejahteraannya.

\section{UCAPAN TERIMA KASIH}

Penulis mengucapkan terima kasih kepada Direktorat Riset dan Pengabdian Masyarakat yang telah membiayai pengabdian kepada masyarakat untuk tahun pelaksanaan 2019. Selanjutnya, penulis juga mengucapkan terima kasih kepada Universitas Teknokrat Indonesia sebagai tempat penulis mengajar sebagai dosen dan sebagai afiliasi untuk mengajukan program kemitraan masyarakat ini dan terima kasih juga untuk SDN 4 Mesuji Timur baik kepala sekolah, guru-guru, dan staff yang sangat kooperatif dalam setiap pertemuan dan kegiatan. Tidak lupa pula terima kasih diucapkan kepada masyarakat Mesuji Timur dan sekitarnya.

\section{DAFTAR PUSTAKA}

Azhariadi, I. D., \& Geni, Z. L. (2019). Pembelajaran Berbasis Teknologi Informasi dan Komunikasi (TIK) di Daerah Terpencil. Seminar Nasional Pendidikan Program Pascasarjana Universitas PGRI Palembang. Palembang. 2019.

Ekosusilo, M. (2014). KTI Pengembangan Profesi Guru. Workshop Penulisan Karya Ilmiah bagi Guru, Kepala Sekolah, dan Pengawas Sekolah. Wonosari. 6-11 November 2014. 


\section{INTEGRITAS : Jurnal Pengabdian}

Vol 4, No 2, Desember 2020

ISSN 2580 - 7978 (cetak) ISSN 2615 - 0794 (online)

Musdiani. (2019). Analisis Model Pembelajaran Terhadap Cara Mengajar Guru untuk Meningkatkan Minat Belajar Siswa pada Materi Penggolongan Hewan di kelas V SD Negeri Pante Cermin. Jurnal Tunas Bangsa. 6(1): 6068.

Noorjanah, L. (2014). Pengembangan Profesionalisme Guru Melalui Penulisan Karya Tulis Ilmiah bagi Guru Profesional Di Sma Negeri 1 Kauman Kabupaten Tulungagung. Jurnal Humanity. 10(1): 97-114.

Oktaviani, L., and Desiarti, E. M. (2017). A Lecturer's and Students' Perspective toward Ethnic Snake Game in Speaking Class at Universitas Muhammadiyah Malang. Teknosastik: Jurnal Bahasa dan Sastra. 15(2): 5359 DOI: $10.33365 /$ ts.v15i2.98.

Permana, H. J. (2010). Penelitian Tindakan Kelas. Seminar dan Lokakarya Diklat Profesi Guru. Pontianak. 2010.

Republik Indonesia. (2005). Undang-undang No. 14 Tahun 2005 Tentang Guru dan Dosen. Lembaran Negara RI Tahun 2005, No. 1. Jakarta: Sekertariat Negara.

Salamah, U., \& Oktaviani, L. (2019). Slidesgo: Peningkatan Motivasi Belajar Siswa Kelas VI pada Materi Perkembangbiakan Hewan. Seminar Nasional Pendidikan FKIP Universitas Lampung. Bandarlampung. 28 September 2019.

Shabir, M. U. (2015). Kedudukan Guru sebagai Pendidik: Tugas dan Tanggung jawab, Hak dan Kewajiban, dan Kompetensi Guru. Auladuna. 2(2): 221232.

Sinaga, R. R. F., \& Oktaviani, L. (2020). The Implementation of Fun Fishing to Teach Speaking for Elementary School Students. Journal of English Language Teaching and Learning. 1(1): 1-6.

Siswanto. (2008). Program Sertifikasi Guru (Antara Tuntutan Kesejahteraan dan Kualitas). Tadrîs. 3(2): 211-221.

Tafonao, T. (2018). Peran Media Pembelajaran dalam Meningkatkan Minat Belajar Mahasiswa. Jurnal Komunikasi Mahasiswa. 2(2): 103-114. 


\section{INTEGRITAS : Jurnal Pengabdian}

Vol 4, No 2, Desember 2020

ISSN 2580 - 7978 (cetak) ISSN 2615 - 0794 (online)

Warsono. (2017). Guru: Antara Pendidik, Profesi dan Aktor Sosial. The Journal of Society \& Media. 1(1): 1-10.

Yamin, M. (2017). Metode Pembelajaran Bahasa Inggris di Tingkat Dasar. Jurnal Pesona Dasar. 1(5): 82-97.

(2017). Permendikbud Nomor 37 Tahun 2017 Pasal 1 Ayat 2 Tentang Sertifikasi Bagi Guru dalam Jabatan yang diangkat sampai dengan Tahun 2005. Jakarta: Kemendikbud. 